\title{
A HAZAI TERMELŐI MÉZEK ÉS MÉHÉSZETI TERMÉKEK IRÁNTI FOGYASZTÓI BIZALOM KVALITATÍV VIZSGÁLATA
}

\author{
Mezőné Oravecz Titanilla - Kovács Ildikó
}

\begin{abstract}
Absztrakt: Az elmúlt évek mézbotrányai miatt számos alkalommal merült fel a mézzel kapcsolatban az élelmiszer-egészségügyi kockázat lehetősége. A hatósági vizsgálatok során szabálytalan feldolgozási módokra, a mézbe került idegen anyagokra és számos mézhamisításra is fény derült. A fogyasztói bizalom növelése érdekében az Országos Magyar Méhészeti Egyesület számos intézkedést tett, többek között bevezette a magyar termelői mézesüveg és zárszalag használatát, és rendszeres vizsgálatokat végez a hazai mézek megfelelőségének vizsgálatára. Kutatásunk a hazai mézfogyasztási- és vásárlási szokások, a fogyasztói preferenciák és attitűdök legmarkánsabb vonásainak megismerését szolgálta. A kutatás során a mézvásárlói- és fogyasztói szokások vizsgálata mellett elemeztük a hazai termelői mézek megítélését, valamint a fogyasztók márkaismeretét. Emellett 10 évre visszamenőleg elemeztük az Országos Magyar Méhészeti Egyesület mézvizsgálatainak eredményeit, a mézek HMF (Hidroximetil-furfurol), fruktóz, glükóz és szacharóz tartalmára, diasztáz enzim aktivitására és a méz eredetiségére vonatkozóan. A kvalitatív adatfelvételt egyéni mélyinterjúk keretében valósítottuk meg, amely során félig strukturált vezérvonalat alkalmaztunk. A felmérés során 86 egyéni mélyinterjút készítettünk, melyek eredményeit jelen tanulmányunkban mutatjuk be.
\end{abstract}

\begin{abstract}
Scandals of recent years related to honey have raised the attention on many occasions to the risk of food health. In the course of official investigations, irregular processing methods, foreign substances in honey and numerous adulterations of honey have been discovered. In order to increase consumer confidence, the National Association of Hungarian Beekeepers has taken a number of measures, including the use of Hungarian producers' glass and sealing tape, and regularly examines the suitability of domestic honey. Our research focused on the most remarkable characteristics of domestic honey consumption and shopping habits, consumer preferences and attitudes. In the course of the research, besides the examination of the consumer habits, we analysed the perception of domestic producers' honey and the brand awareness of consumers. In addition, we analysed the 10 year results of the honey examinations made by the National Association of Hungarian Beekeepers: HMF (Hydroxymethyl-furfurol), fructose, glucose and sucrose content of the honey, diastase enzyme activity and origin of honey. The qualitative data collection was carried out in the framework of individual in-depth interviews, during which we used a semi-structured guideline. 86 in depthinterviews were conducted during the survey, the results of which are presented in this paper.
\end{abstract}

Kulcsszavak: méz, mézhamisítás, élelmiszerbiztonság, fogyasztói magatartás

Keywords: honey, honey adulteration, food safety, consumer behaviour

\section{Bevezetés}

A mézhamisítás problémájának hosszú történetét igazolja, hogy már Báró Ambrózy Béla már 1896-ban is megfogalmazta a mézhamisítással kapcsolatos legnagyobb problémát, miszerint a méz az egyik legkönnyebben hamisítható élelmiszer. A fogyasztók számára szinte lehetetlen megkülönböztetni a hamis és az eredeti terméket, így a nehéz felismerhetőség remek lehetőséget nyújt a hamisítók számára.

Az élelmiszer-biztonság, mind a termelők, gyártók és forgalmazók alapvető célja. A magyarországi forgalomban lévő élelmiszerek csak és kizárólag a legszigorúbb hazai és uniós minőségügyi, valamint élelmiszerbiztonsági 
jogszabályok betartásával juthatnak el a fogyasztókhoz, a bizonytalan eredetü hamisított termékekre azonban ez nem vonatkozik. Ez nem jelenti azt, hogy ezek a termékek feltétlenül károsak lennének az egészségre, de összetételük ismerete nélkül az ellenkezőjét sem állíthatjuk. Egészségesnek kizárólag a biztonságos élelmiszereken alapuló, változatos táplálkozást tekinthetjük (Fodor, 2018), ami mézfogyasztás esetében a méz minőségére, eredetére és a termelő megbízhatóságára egyaránt vonatkozik. Bár a hamis méz minősége alulmarad az eredeti méz minőségével szemben, mind élvezeti érték, mind tápanyagtartalom tekintetében (Ambrózy, 1896; Horváth - Mezőné 2019), de az esetek többségében ezek a termékek élelmiszerbiztonsági szempontból nem feltétlenül ártalmasak (Fodor, 2018).

Az egészséges élelmiszerek iránti igény a fogyasztók részéről az utóbbi években egyre nő, a termékek kiválasztása során a minőség szerepe felértékelődött (Szakály, 2011; Töröcsik, 2007), amely az egészség-magatartás pozitív irányú változásában, mint a tudatos táplálkozásban is megmutatkozik (Szakály, 2011). A Központi Statisztikai Hivatal (2018) jelentése alapján növekedett az egy före jutó hazai élelmiszerfogyasztás, az egy före jutó hazai éves mézfogyasztás a 2010-ben jegyzett 30 dekagrammról 80 dekagrammra emelkedett (Feldman, 2018). A mézfogyasztás felértékelődését magyarázza, hogy a méz azon ritka táplálékok egyike, amely emberi beavatkozás nélkül kerülhet a fogyasztók asztalára (Árváné és mtsai., 2010), csak természetes alapanyagokból áll, mentes minden hozzáadott adalékanyagtól, tartósítószertől. A Magyar Élelmiszerkönyv (Codex Alimentarius Hungaricus) 1-32001/10 sz. elöírása alapján: „A méz, az Apis mellifera méhek a növényi nektárból vagy élő növényi részek nedvéből, illetve növényi nedveket szívó rovarok által az élő növényi részek kiválasztott anyagából gyüjtött természetes édes anyag, amelyet a méhek begyüjtenek, saját anyagaik hozzáadásával átalakítanak, raktároznak, dehidratálnak, és lépekben érlelnek."

Tanulmányunkban a 2017 márciusa és áprilisa között lefolytatott kvalitatív interjúk eredményeit ismertetjük. A kutatásunk során alapvető célunk volt a mézzel kapcsolatos fogyasztói és vásárlói szokások felmérése, a fogyasztói bizalom vizsgálata, a méz fogyasztói megítélésének elemzése, legmarkánsabb vonásainak megismerése. Mindezek mellett 10 évre visszamenőleg elemezzük az Országos Magyar Méhészeti Egyesület mézvizsgálatainak eredményeit, a mézek HMF (Hidroximetil-furfurol), fruktóz, glükóz és szacharóz tartalmára, diasztáz enzim aktivitására és a méz eredetiségére vonatkozóan.

\section{Anyag és módszer}

Kvalitatív vizsgálatunk egy többlépcsős kutatási folyamat első fázisa volt. Empirikus vizsgálataink során azt a célt tartottuk szem előtt, hogy olyan információkat tárjunk fel, amelyek segíthetnek kijelölni a hazai méhészeti ágazat képviselői számára a legfontosabb marketingstratégiai döntések irányát. Kutatásuk célja olyan kvalitatív információk feltárása volt, amely segíthet a hazai termelői mézeket forgalmazók számára a termékfejlesztéssel és értékesítéssel kapcsolatos kérdésekben. Kvalitatív kutatásunk alapvetően a hazai mézfogyasztási- és vásárlási szokások, a fogyasztói 
preferenciák és attitüdök legmarkánsabb vonásainak megismerését szolgálta, továbbá segített egy későbbi, kvantitatív kutatás koncepciójának megalapozásában. Későbbi kutatásunk célja lesz számszerüsíteni a kvalitatív kutatásunk által feltárt eredményeket, továbbá megvizsgálni a célcsoport reprezentatív mintáján a feltárt jelenségek alakulásának arányait.

A kvalitatív adatfelvételt egyéni mélyinterjúk keretében valósítottuk meg, amely során félig strukturált vezérvonalat alkalmaztunk (Hoffmann és mtsai, 2000; Malhotra, 2005). A mélyinterjú-vezérfonal fö kérdéskörei a következők voltak: mézvásárlási- és fogyasztói szokások, a hazai termelői mézek megítélése, a mézfogyasztással kapcsolatos attitüdök valamint a hazai termelői mézek márkaismerete. Az adatfelvétel 2017 márciusa és áprilisa között zajlott, összesen 86 kéziratot értékeltünk hagyományos tartalomelemző módszerrel. Az interjú alanyainak kiválasztása során a következő szürőfeltételt alkalmaztunk: olyan 18. életévüket betöltött személyek vehettek részt a vizsgálatban, akik legalább havi rendszerességgel fogyasztanak mézet és részt vesznek a mézvásárláskor a termék kiválasztás folyamatában.

\section{Eredmények és értékelésük}

\subsection{Fogyasztói szokások és attitüdök}

A megkérdezettek értékítéletében kedvező helyet foglal el a méz, a legtöbb asszociáció pozitív fogyasztói megítélésről tanúskodott. Az említések alapján arra következtethetünk, hogy a megkérdezettek egészséges, értékes beltartalommal rendelkező, természetes cukorhelyettesítőként tekintenek a mézre. A megkérdezett fogyasztók többsége elsősorban azért fogyaszt mézet, mert ezáltal szeretnék megvédeni egészségüket, hozzájárulni szervezetük egészséges müködéséhez, javítani közérzetükön. A fiatalabb generáció tagjai főleg édesítőszerként használják a mézet, míg az idősebb generáció képviselői nem csak édesítő hatása miatt kedvelik, hanem egészségmegőrzés céljából is fogyasztják, és különböző gyógyhatásai miatt preferálják az egyes fajtákat. A méz fogyasztói szokások egyértelműen eltérnek a generációk között, amit Šedík és mtsai (2018) kutatási eredményeiben is megtalálhatunk.

A mézet étkezési, gyógyítási célok mellett szépségápolásra is használják a legkülönbözőbb formákban: sampon, balzsam, tusfürdő, testápoló, hajfesték, arckrém, bőrradír, pakolás, masszázskrém, szauna kozmetikum, ajakír. Néhányan találkoztak már mézes illatosítóval és bútorápolóval is. Különösen a fiatalabb válaszadókra volt jellemző, hogy nagyobb szellemi, fizikai erőfeszítés, sportolás, tanulás esetén használják teljesítményfokozó gyanánt: , manapság nagyon betört az egészségtudatos táplálkozás, és az emberek egy része próbál minél kevesebb szénhidrátot, ezen belül is leginkább cukrot fogyasztani, de teljesítmény fokozásra a legjobb természetes szer".

Már a spontán említések is a mézfogyasztás szezonális növekedését sejttették, amelyet a fogyasztási szokások alapos vizsgálata alá is támasztott. A megkérdezett fogyasztók többsége a hüvösebb, megfázásos, jellemzően őszi és téli, szezonális 
időszakban több mézet fogyaszt az év többi részéhez képest. Dr. Ludányi István (2019) a méhészet tudományok doktora és gyakorlott méhész meglátása szerint is szezonalitás figyelhető meg a mézfogyasztói szokásokkal kapcsolatban, szeptembertől december végéig lényegesen megnő a mézvásárlás az év többi időszakához képest. Ez általában forró mézes tea formájában történik: "Általában a téli, megfázós időszakban többször fogyasztok mézet, egyrészt mert rendkivül egészséges, másrészt ha beteg vagyok mindig a mézes-citromos-gyömbéres tea ez elsö...",Általában egy két kanállal fogyasztok naponta, teába, kávéba beletéve édesitöszerként, de amikor beteg vagyok, akkor nagyobb mennyiségben fogyasztok." Néhányan sérülésekhez, házi gyógyításhoz használnak mézet, jellemzően külsőleg: „horzsolásokra, sebekre is kiváló”, „a kislányom problémás börére és az én ráncaimra is jótékony hatással van a méz".

Ebben az időszakban több mézet és jellemzően nagyobb, gazdaságosabb kiszerelésben vásárolnak. Túlnyomó többségük közvetlenül termelőtől szerzi be a mézet, ők teljes mértékben elzárkóznak a boltban kapható mézektől, az esetek többségében a megszokott termelötől vásárolnak. Akadnak azonban olyan megkérdezettek is, akik kizárólag a boltokban kapható mézeket részesítik előnyben, termékválasztásukat elsősorban az ár és az elérhetőség befolyásolja: Azok a megkérdezettek, akiknek az elérhetőség az elsődleges szempont jellemzően termelöi és bolti mézet egyaránt vásárolnak.

A fogyasztók egy másik, jól elkülöníthető csoportja szintén szezonálisan fogyasztja a mézet, de ők nem gyógyászati céllal fogyasztják. Ez a fogyasztói csoport jellemzően az Adventi ünnepi időszakban és Karácsonykor fogyaszt jelentősen több mézet, általában ünnepi ételek, italok, különböző mézes sütemények és mézeskalács formájában. Saját bevallásuk szerint családi körben, a Húsvéti időszakban is megnő a mézfogyasztás. Ők a méz szó hallatán jellemzően családi összejövetelre, gyerekkori emlékekre asszociáltak.

A méz magas cukortartalmából adódó hizlaló határa is jellemző említés volt, bár mértékletes fogyasztása jótékony hatással van az emberi szervezetre: „Nem szabad túlzásba vinni a fogyasztását a sok cukor miatt, az arany középutat kell megtalálni”, „, igyekszem mindenböl a megfelelö mennyiséget fogyasztani, se sokat, se keveset, így van ez a mézzel is".

A fogyasztók egyértelműen a hazai mézet tartják jobb minőségünek: „Hazai méz csakis, azért mert a szervezetünknek mindenképpen jobb az a méz, amit a környezetünkben lévő növényekről gyüjtenek a méhek és ezzel támogatjuk a magyar gazdaságot, jobban bízok a magyar termékekben.” Néhányan nem zárkóznak el a külföldről származó méhészeti termékektől, akác, hárs és virágmézet nem szívesen, viszont külföldi mézkülönlegességeket szívesen kipróbálnak és vásárolnak is. Az újdonságokat jellemzően kis kiszerelésben vásárolják, ennek egyrészt az ismeretlentől való félelem az oka, másrészt a különlegességek csak kisebb kiszerelésekben és az átlagártól magasabb áron kaphatók. Ezekre a termékekre a fogyasztók hajlandók magasabb összeget kiadni, különösen, ha nem saját fogyasztásra szánják, hanem ajándékba vásárolják. 
A környezettudatos fogyasztók élelmiszer vásárlási szokásait jelentősen befolyásolja a környezetvédelem, a megkérdezettek válaszai megerősítették Bence és mtsai (2016) erre vonatkozó kutatási eredményeit, vagyis, ezen fogyasztók számára kimondottan fontos, hogy környezetbarát, visszaváltható vagy újrahasznosítható csomagolású termékeket fogyasszanak, kifejezetten preferálják a helyi termékeket. Az üveg környezetbarát csomagolóanyag, nem oldódnak ki belöle káros anyagok, többször felhasználható, tökéletesen megörzi a benne tárolt élelmiszer, esetünkben a méz tisztaságát, minőségét. (Árváné és mtsai, 2010) Bence és mtsai (2016) eredményei szerint a kevésbé környezettudatos fogyasztók is ezt a csomagolást preferálják, azonban esetükben ennek inkább anyagi okai vannak, mint környezetvédelmi. Ez igaz a megkérdezettekre, a méze estében az üveget a környezettudatos vásárlók részesítik előnyben, a müanyag csomagolást az árérzékenyebbek. Csak az ajándékba vásárlás esetében hangsúlyozták a csomagolás fontosságát, ott viszont a fajta után ez az elsődleges szempont: „legjobb karácsonyi ajándék a méz”, „,csodálatos csomagolásuk szemet gyönyörködtető”.

$\mathrm{Az}$ élelmiszerek megítélésében a minőség szerepe kiemelkedő, a hazai fogyasztók egy része az alacsony jövedelemszint és a magas árak miatt bizonyos esetekben kénytelenek lemondani a magas minőségü termékekről, és vásárlásaik során kénytelenek a számukra megfelelő ár-érték arányú termékeket előtérbe helyezni. (Szakály, 2004). Törőcsik (2007) álláspontja szerint hiába tekinti értéknek a magyar vásárlók jelentős része az egészséges, természetes alapanyagokból előállított, vegyszermentes élelmiszereket tényleges vásárlásaikban ez nem jelenik meg. A fogyasztók ténylegesen megvalósult vásárlási döntéseit jelentősen befolyásolja az adott termék és a helyettesítő termék ára, az akciók és az egyéb olyan marketingeszközök, amelyek a ,jól vásároltam” érzést válthatják ki a fogyasztókból. Ez a méz esetében sincs másképp, a méz viszonylag magas fogyasztói ára miatt sok fogyasztó lemond róla, hiába tartja táplálkozás-élettani szempontból kedvezőnek a fogyasztását. A mézet jellemzően cukorral vagy egyéb édesítőszerekkel helyettesítik (Urbánné-Treutz, 2017).

A megkérdezettek átlagosan 1880 Forintot költenek egy kilogramm mézre (Jelenleg az akácméz és a hársméz átlagára $2000 \mathrm{Ft}$, a vegyes virágmézé $1400 \mathrm{Ft}$ körül mozog (Ludányi-Mezőné, 2019))., a vegyes virágmézre kevesebbet, az akácra és a gesztenyére többet. Több interjúalanynál megjelent az ajándékba vásárlás, és a különleges, kézmüves termékekre való igény, mint például a diós, mandulás, levendulás, mentás és a mézkülönlegességek.

Eredményeink, - hasonlóan Erdélyi (1999) és Árváné Ványi (2011) korábbi kutatási eredményeihez - a méz egészségre, kedvező táplálkozás-élettani és gyógyhatásaira vonatkozó említések száma az összes említés jelentős hányadát képviselték. Ezek alapján egyetértünk Árváné (2011) azon megállapításával, hogy a fogyasztók tudatában a méz és az egészség egymással kapcsolatban álló fogalmak a fogyasztók gondolkodásában. 


\subsection{Fajtaméz preferenciák}

A fajtaméz preferenciákat tekintve a fogyasztók elsősorban a klasszikus ízeket részesítik előnyben, a legnépszerübb az akác és a vegyes virágméz: „Az akácméz a kedvencünk, kellemes állaga, íze miatt szinte minden nap használom!”. A hárs, repce, gesztenye fenyő, selyemfü méz is kedvelt fajtának bizonyult. Az említett és toronymagasan vezető akácon és virágmézen túl, különösen a hölgyek körében volt népszerü a levendula, napraforgó, narancs, málna és szederméz. A fajtaméz preferenciák tekintetében meg kell említenünk, hogy a megkérdezettek többsége a termelői mézet részesíti előnyben íz preferencia nélkül, a személyes háztól vagy piaci értékesítésnél a termelői garancia fontosabb a fajtánál: ,jobb izü és szebb is a termelöi méz, mindegy, hogy milyen fajta".

A hagyományos mézek mellett népszerủek voltak a hazai mézkülönlegességek is, mint a különböző, ízesített mézek vagy az aszalványok, magvak hozzáadásával készült mézek. Az ízesített mézek sokaságával találkozhatunk a termelőknél, a megkérdezettek a következő termékeket említették: bodzás, citromfüves, chili paprikás, fokhagymás, kapros, fahéjas és mentás méz. Az aszalványok, magvak hozzáadásával készült mézek közül az akácba kevert diákcsemege, dió, mogyoró, mák, kávé, kandírozott narancs és tökmag került említésre, de népszerüek voltak a propolisz és virágpor hozzáadásával készült mézek is.

\subsection{A vásárlás helyszíne}

A méz esetében gyakori a háznál való értékesítés, amely nagy népszerüségnek örvend a fogyasztók körében. A méhészek gyakran jelennek meg termékeikkel a helyi termelői piacokon is, amelyet az egészségtudatos fogyasztók előszeretettel látogatnak. Számukra kiemelkedően fontos a személyes kapcsolat a termelővel, ami számukra egyfajta minőségbiztosítást jelent. Mind a nemzetközi, mind pedig a hazai piacon is folyamatos az online értékesítés növekedése, azonban a vásárlók számára a fizikai élmény is fontos, amelyet a vásárlásaik során átélnek. A vásárlók folyamatosan keresik a vásárlási élményeket, amelyet a többek között piacra járás is képes kielégíteni (Turcsán, 2019). A megkérdezettek jellemzően szeretnek piacon vásárolni, és fizikai kapcsolatba kerülni a termékkel. A fogyasztók többsége a termelői magyar mézet keresi a piacokon, a méhésszel való személyes kapcsolat egyfajta minőségi garanciát jelent számukra. A megkérdezettek döntő többsége előnyben részesíti a hazai mézeket, a külföldi származású mézekkel szemben, ami hasonló eredmény Árváné Ványi (2011) korábbi kutatásával. Egymástól jelentősen eltérő fogyasztói szokások és preferenciák figyelhetők meg a megkérdezettek körében: az egyik szegmens számára kiemelkedő fontosságú a termelő ismerete és szinte kizárólag háztól vagy piacon ismert termelőtől vásárolnak. Ök egyfajta élményként élik meg a vásárlást, nem részesítik előnyben az online vásárlást: „, szeretek kimenni a piacra, östermelötöl vásárolni meg a mézet”, „Östermelőnél nem gyakori az online vásárlási lehetöség, de igazából nem is hiányzik vagy nem is részesitem elönyben, hogy online tudjak rendelni. Én szívesen nyakamba veszem a várost és elindulok vásárolni, ez is egyfajta kimozdulás.”, ,Imádok kimenni a piacra, beszélgetni egy jót a termelövel, meghallgatni, mi újság a méhecskékkel, ettöl kicsit 
magaménak érzem a mézet is." Néhányan teljes mértékben elutasítják az online vásárlás lehetőségét a méz esetében: „online nem vásárolnék mézet, fontos a személyes kapcsolat”. „Semmiképpen sem vásárolnék online, én szeretem látni a kipakolt termékeket, és a mögötte álló kedves, östermelö nénit.”, „ki tudja ki és hogyan termelte a mézet, nem merek kockáztatni”.

A másik jól elkülöníthető szegmens számára a legfontosabb tényezők a könnyű beszerezhetőség és az ár, számukra főként a nagyobb üzletek jelentenek alternatívát a mézek beszerzésére. Ennek a szegmensnek a kiszolgálására az utóbbi években a termelök megjelentek az interneten és a közösségi médiában is, egyre több értékesítési csatornán keresztül próbálják meg értékesíteni termékeiket, számos új vevőt nyertek (Ludányi-Mezőné, 2019).

\subsection{A hazai termelői mézek márkaismerete}

A megkérdezettek márkaismerete hiányosnak nevezhető a méhészeti termékek tekintetében, közülük csak néhányan tudtak konkrét márkát megnevezni, ezek a következők voltak: Kincses-Billege Termelői Vándorméhészet, Ludányi Méhészet, Koós Méhészet, Klenáncz és az Aranynektár. A többiek csak a méhészt tudták megnevezni, akitől rendszeresen vásárolnak: „Laci bácsi a szomszéd utcából”, „a néni a piacon”, „a mama mindig Pali bácsihoz megy mézért”, „Zoliék a vásárcsarnokból”, vagy még nevet sem tudtam mondani: „termelő”, „méhész”, „Piaci árus”, „egy méhész ismerősöm”. A többség ragaszkodik a megszokott termelöhöz, de szükség esetén más termelőktől vásárolnak, mézvásárláskor a személyes kapcsolaton és megbízhatóságon van a hangsúly. Következtetésként megállapíthatjuk, hogy nincs elegendő jól csengő, közismert márka a hazai mézpiacon, amit a fogyasztók ismernek, ezt Kopcsay (2019) kutatása is igazolja.

\subsection{Mézhamisítás}

Az elmúlt évek mézbotrányait javarészt olyan hamisítások okozták, amelyek esetében a méz összetétele nem felelt meg az elöírásoknak (MÉK, 2002) vagy a címkén feltüntetett megnevezésnek. A hamis méz minősége alulmarad az eredeti méz minőségével szemben, mind élvezeti érték, mind tápanyagtartalom tekintetében (Ambrózy, 1896; Horváth-Mezőné 2019), de az esetek többségében ezek a termékek élelmiszerbiztonsági szempontból nem feltétlenül ártalmasak.

A forgalomban lévő mézekkel, különösen a számukra ismeretlen eredetű és a nagy áruházláncok termékeivel kapcsolatban többen bizalmatlanok:

„Úgy tudom, hogy a hipermarketekben kapható mézeket rendszerint hamisítják”, „Nagyon sok hírt lehet hallani a mézhamisitásról és ezért a szupermarketek polcain lévö mézekkel szemben bizalmatlan vagyok."

„Nem egy hír volt a TV-ben is, hogy bevizsgálták a nagy áruházak polcain található külföldi mézet, és nagy része hamisítvány volt. Annyival pedig nem lehet drágább a magyar, hogy bevállaljam ezt a kockázatot."

„Nem szivesen vennénk szupermarketekböl, sok rosszat hall az ember, hogy milyen mézet árulnak ott. Értem ezalatt, a külföldröl behozott hamisítványokat."

„Félünk a hamis méztöl.” 
A hamis méz értékesítése által a fogyasztók minden esetben megkárosodnak, mivel nem mézet, hanem méznek nem nevezhető egyéb terméket, jellemzően cukorszirupot adnak el számukra méz helyett, de az élelmiszer-hamisítások során csak a fogyasztók károsodnak, hanem a termelők is, hiszen a hamisítások a termékük piacát is rontják (Fodor, 2018).

\subsection{Mézvizsgálati eredmények}

Az Országos Magyar Méhészeti Egyesület (OMME) mérési eredményei alapján mutatjuk be a mézvizsgálatok eredményeit az utolsó 10 év tekintetében. A valódi magyar méz, a magyar termelők és fogyasztók védelme, valamint a hamisítás visszaszorítása érdekében az OMME egyedi mézesüveget és zárszalagot biztosít a tagok számára. Ezen lehetőségek elsődleges célja, hogy tájékoztassa a mézfogyasztókat arról, hogy a forgalomban lévő mézek közül melyek a biztosan természetesek és magyar méztermelőtől származóak. Az OMME az éves vizsgálatok során a legfontosabb, a hatályos Élelmiszerkönyvben meghatározott paramétereket vizsgálták: a szacharóz-, fruktóz- és glükóztartalom, HMF tartalom, diasztáz aktivitás, mézeredet (pollenanalízis), hamisításvizsgálat, illetve idegen enzim aktivitás. A vizsgálati eredményeket az alábbi táblázat szemlélteti a vizsgálat során nem megfelelő értékkel rendelkező minták tekintetében 2008 és 2018 között.

Az OMME a hazai méhészek, a tisztességes mézkiszerelők, mézexportőrök és a mézfogyasztók érdekében mindent elkövet, hogy a hazai méhészeti ágazat megszabaduljon a tisztességtelen eszközöket használó szervezetektől. Az egyesület tevékenysége leginkább a szakmában résztvevők, és a fogyasztók tájékoztatására koncentrál a forgalomban kapható mézek minőségéről. A vizsgált minták eredményeinek értékelése, -- természetesen a termelő, a gyártó és a forgalmazó feltüntetésével -- a Méhészet és a Méhész Újság szaklapokban, illetve az OMME hivatalos oldalán is elérhető a felhasználók számára.

Az OMME a vizsgálatai során bolti és zárszalagos mézeket is bevizsgál minden évben, az elvégzett szúrópróba szerü mézvizsgálatok évente átlagosan 51 termelői mézet érintenek, illetve több bolti mézet (1. táblázat), szemben a hazánkban tevékenykedő 23.000 méztermelővel (OMME, 2019). Az adatokból jól látszik, hogy a nem megfelelő minőségü mézek aránya kiugróan magas az egyes években. Az OMME vizsgálatain túlmenően is történnek azonban minőségi mérések, a termelők illetve a felvásárlók kezdeményezésére. Árváné és mtsai álláspontja szerint: ,,a méz ténylegesen egy bizalmi élelmiszernek számít, hiszen az oly kedvelt termelői mézzel kapcsolatban csupán bízhatunk a termelőben, hogy tényleg valódi és kiváló mézet ad el nekünk, hiszen nagyon kicsi az esélye annak, hogy hatóság által bevizsgált és ellenőrzött mézet vásárolunk meg." (Árváné és mtsai, 2010, p. 195.) 


\section{1. táblázat: Az OMME mézvizsgálatai során nem megfelelő értékkel rendelkező minták száma (db), 2008-2018}

\begin{tabular}{|c|c|c|c|c|c|c|}
\hline Év & $\begin{array}{c}\text { Mézminták } \\
\text { száma összesen } \\
(\mathrm{db})\end{array}$ & $\begin{array}{c}\text { HMF } \\
\text { tartalom }\end{array}$ & $\begin{array}{c}\text { Diasztáz } \\
\text { enzim } \\
\text { aktivitás }\end{array}$ & $\begin{array}{c}\text { Hamisítás } \\
\text { vizsgálat }\end{array}$ & $\begin{array}{c}\text { Fruktóz- } \\
\text { glükóz } \\
\text { tartalom } \\
(\mathrm{g} / 100 \mathrm{~g})\end{array}$ & $\begin{array}{c}\text { Szacharóz- } \\
\text { tartalom }\end{array}$ \\
\hline 2008 & 54 & 5 & 4 & 9 & 9 & 0 \\
\hline 2009 & 103 & 7 & 3 & 0 & 2 & 4 \\
\hline 2010 & 116 & 4 & 4 & 3 & 1 & 1 \\
\hline 2011 & 134 & 6 & 14 & 12 & 0 & 0 \\
\hline 2012 & 146 & 4 & 3 & 3 & 0 & 0 \\
\hline 2013 & 150 & 9 & 0 & 0 & 1 & 11 \\
\hline 2014 & 114 & 1 & 3 & 1 & 0 & 0 \\
\hline 2015 & 141 & 5 & 5 & 3 & 2 & 3 \\
\hline 2016 & 69 & n.a. & n.a. & n.a. & n.a. & n.a. \\
\hline 2017 & 118 & 3 & 2 & 0 & 0 & 0 \\
\hline 2018 & 119 & 1 & 22 & 0 & 3 & 6 \\
\hline
\end{tabular}

Forrás: OMME Ügyvezetés: 2009-2013, Horváth: 2014a, 2014b, 2015, 2016, 2017, 2018 alapján saját szerkesztés, 2019

\section{Következtetések, összegzés, záró megjegyzések, záró gondolatok}

A kutatásunk során alapvető célunk volt a hazai méhészeti termékekkel kapcsolatos fogyasztói percepciók, a fogyasztói preferenciák legmarkánsabb vonásainak megismerése, a magyar méz fogyasztói megítélésének elemzése. Eredményeink szerint kvalitatív vizsgálatunk eredményei alapján sikerült olyan újszerü információkat feltárni, amelyek irányt képesek mutatni a hazai méhészeti ágazat képviselői számára a hatékony marketingszemlélet megvalósításához, és úgy az ágazati közösségi, mint a vállalati marketingstratégia kialakításához.

A jelen kutatás eredményei is igazolják Lászlóffy (2014) korábbi eredményeit, miszerint a fogyasztók mézről alkotott képe egyértelmúen javult az elmúlt években, nőtt a mézfogyasztás, a fogyasztók egészséges és természetes édesítőszerként tekintenek a mézre. Megállapíthatjuk, hogy a megkérdezettek a mézre egészséges és természetes édesítőszerként tekintenek, amely a tradicionális jellege mellett egyedi értékek hordozója. Mindez azt igazolja, hogy az évekkel korábban megkezdett közösségi marketingtevékenység (Mézes Reggeli, Mézzel Lélekkel kampány) és az ebből eredő kommunikációs stratégia irányvonalai helyesek, a tájékoztatás szakasza hatékony volt (Horváth-Mezőné, 2019). Természetesen akad még feladat bőven, de az eredmény mindenképp pozitív tendenciát igazol.

Interjúalanyaink válaszait összevetve megállapíthatjuk, hogy a vásárlók általánosságban tájékozottak, mézfogyasztási szokásaikban többnyire tudatosak. A fogyasztók bizalma kezd megszilárdulni a hazai méhészeti ágazat irányában. A bemutatott eredmények, mind alátámasztják, hogy a megkérdezett fogyasztók tudatosan és egyre gyakrabban fordulnak az általuk egészségesebbnek, jobb ízünek 
vélt és egyben igazolt eredetű magyar termelői mézek felé, amely tendencia hatalmas lehetőséget jelent a magyar méhészeti ágazat számára.

\section{Irodalomjegyzék}

Ambrózy B. (1896): A méh. Csanád-egyházmegyei Könyvnyomda. Temesvár.

Árváné Ványi G. (2011): A mézpiac marketing szempontú elemzése különös tekintettel a fogyasztói és vásárlói magatartásra. Doktori $(\mathrm{PhD})$ Értekezés. Debreceni Egyetem, Agrár- és Gazdálkodástudományok Centruma, Gazdálkodástudományi és Vidékfejlesztési Kar, Gazdálkodástudományi Intézet. Ihrig Károly Gazdálkodás- és Szervezéstudományok Doktori Iskola. Debrecen.

Árváné Ványi G. Csapó Zs., Kárpáti L. (2010): Mézfogyasztói szokások és a mézminőség fogyasztói megítélése az Észak-Alföldi régióban, In: Csépe Andrea (szerk.): „Új Marketing Világrend”. Egyesület a Marketing Oktatásért és kutatásért (EMOK) XVI. országos konferencia: Tanulmánykötet. Budapesti Kommunikációs és Üzleti Főiskola Marketing Intézete Budapest. pp. 193-212.

Bence K., Lábodi L., Böröndi-Fülöp N. (2016): A környezetvédelem szerepe az élelmiszervásárlásban. In: Élelmiszer, Táplálkozás és Marketing 12 (1): 47-55.

Erdélyi T. (1999): Hazai mézfogyasztási tükör. Szakdolgozat. Berzsenyi Dániel Tanárképző Főiskola. Mủvelődéstudományi és Felnőttképzési Tanszék. Szombathely.

Feldman Zs. (2018): 31. Nemzetközi Mézvásár és Méhésztalálkozó. Megnyitó. Jászberény. 2018.08.04.

Fodor P. (2018): Melyek az élelmiszerbiztonság kritikus pontjai? - Tények és hiedelmek. Letöltve: 2018.12.12. https://agroforum.hu/agrarhirek/eletmod/melyek-az-elelmiszer-biztonsag-kritikuspontjai-tenyek-es-hiedelmek

Hajnal D., Dászkál F. (2019): Élelmiszerfogyasztási trendek 2019. Kutatások, eredmények, prognózisok 2019-re. Magyar Marketing Szövetség, Agrár- és Élelmiszer-marketing Tagozat és a Budapesti Gazdasági Egyetem Marketing Tanszékének ülése. Budapest. 2019.02.06.

Horváth, G. (2014a): Mézvizsgálatok 2014. In: Méhészet 62 (11): 14-16.

Horváth, G. (2014b): Mézvizsgálatok 2014. In: Méhészújság 1 (9): 26-28.

Horváth, G. (2015): Mézvizsgálat, 2015. In: Méhészújság 2 (8): 24-27.

Horváth, G. (2016): Mézvizsgálat, 2016. In: Méhészújság 3 (8): 4-6.

Horváth, G. (2017): Mézvizsgálat, 2017. In: Méhészújság 4 (9): 4-6.

Horváth, G. (2018): Mézvizsgálat, 2018. In: Méhészújság 5 (8): 4-6.

Horváth G., Mezőné Oravecz T.: Szakértői interjú Horváth Gáborral, az Országos Magyar Méhészeti Egyesület vezető szaktanácsadójával. Budapest. 2019.02.19

Hoffmann M., Kozák Á., Veres Z. (2000): Piackutatás. Müszaki Könyvkiadó. Budapest. p. 79-84.

Központi Statisztikai Hivatal (2018): Az egy főre jutó éves élelmiszer-fogyasztás mennyisége a referenciaszemély korcsoportja, iskolai végzettsége és a háztartástagok korösszetétele szerint (2010-2017) http://www.ksh.hu/docs/hun/xstadat/xstadat_eves/i_zhc029a.html

Kopcsay L. (2019): Növelhető a hazai mézfogyasztás. In: Méhészet 67 (1): 10-12.

Lászlóffy Zs. (2014): Mézpiaci információk. In: Méhész Újság, 1 (6): 26-27.

Ludányi I., Mezőné Oravecz T, (2019): Szakértői interjú Dr. Ludányi Istvánnal, a méhészet tudományok doktorával és gyakorlott méhésszel. Gödöllő. 2019.03.04

Magyar Élelmiszerkönyv (2002): 1-3-2001/ 110 sz. elöírás. Méz. Magyar Élelmiszerkönyv Bizottság. Budapest. pp. 1-7.

Malhotra N. K. (2005): Marketingkutatás. Akadémiai Kiadó. Budapest.

OMME Ügyvezetés (2009): Bolti és zárszalagos mézek vizsgálata 2009. In: Méhészet 57 (8): 14-17.

OMME Ügyvezetés (2010): Bolti és zárszalagos mézek vizsgálata 2010. In: Méhészet 58 (7): 12-15.

OMME Ügyvezetés (2011): Mézvizsgálatok 2011. In: Méhészet 59 (8): 14-18.

OMME Ügyvezetés (2012): Mézvizsgálatok 2012. In: Méhészet 60 (8): 18-21.

OMME Ügyvezetés (2013): Mézvizsgálatok 2013. In: Méhészet 61 (8): 18-21.

OMME Ügyvezetés (2019): Adatszolgáltatás 
Šedík P., Prokeinová R. B., Horská E. (2018): Consumption Patterns And Sensory Perception Of Honey By Young Segment In Slovakia. Economics Management Innovation, 10 (3): 1804-1299. Szakály Z. (2004): Táplálkozásmarketing, egy új stratégia a magyar élelmiszer-gazdaságban. Élelmiszer, Táplálkozás és Marketing 1 (1-2): 31-44.

Szakály Z. (2011): Táplálkozásmarketing. Mezőgazda Kiadó. Budapest. p. 66-68.

Törőcsik M. (2007): A tudatos fogyasztást és az egészséget preferáló új fogyasztói trendcsoport a LOHAS csoport megjelenése Magyarországon. In: Élelmiszer, Táplálkozás és Marketing 4 (2): 41-45.

Turcsán T. (2019): Élelmiszerfogyasztási trendek 2019. Magyar Marketing Szövetség, Agrár- és Élelmiszer-marketing Tagozat és a Budapesti Gazdasági Egyetem Marketing Tanszékének ülése. Budapest. 2019.02.06.

Urbánné Treutz Á., Treutz Zs. (2017): Fogyasztói felmérés a mézfogyasztással kapcsolatban. In: Gazdálkodás 61 (4): 355-370.

175/2008. (XII.31.) FVM-rendelet 11. § „A méz fizikai-kémiai tulajdonságai elemzésének támogatása"

121/2009. (IX.11.) FVM-rendelet 14. § „A méz fizikai-kémiai tulajdonságai elemzésének támogatása"

47/2010. (XII.31.) FVM-rendelet 21. § „A méz fizikai-kémiai tulajdonságai elemzésének támogatása” 118/2013 (XII.16.) VM-rendelet, 21. § „A méz fizikai-kémiai tulajdonságai elemzésének támogatása” 4/2017 (I.23.) FM-rendelet, 23. § „A méhészeti termékek elemzését végző laboratóriumok támogatása" 